Ambient Science, 2021: Vol. 08(Sp1); 10-13

DOI:10.21276/ambi.2021.08.sp1.oa02

\title{
The Relationship between Recreational Awareness and Satisfaction with Life: the Case of University Students
}

\section{Mehmet Demirel, Alper Kaya*, Yalçin Tükel, Duygu Harmandar Demirel}

Recreation Management Department (Tourism), University of Necmettin Erbakan, Turkey

Study Area: Konya, Turkey

Coordinates: $37^{\circ} 52^{\prime} \mathrm{N} ; 32^{\circ} 29^{\prime} \mathrm{E}$

Key words: Leisure time, Life satisfaction, Pleasure \& Fun, Social Success, Self improvement.

\section{Introduction:}

The free time which has an important place in social life the concept of time is the most creates a much-needed space (Mutlu et al., 2011). Free time is described as a time frame left of mandatory tasks and utilized at one's will and a period that individuals can express themselves freely (Kara et al., 2018). The concept of recreation, on the other hand, is described as activities that people attend in their free time (Jensen \& Naylor, 2000; Tribe, 2011; Shaw, 1980; Torkildsen, 2005). Recreation is described as any activity that people engage in at their will on their own or as a group in their free time and have fun, rest, and refresh themselves in physical and mental aspects (Ardahan et al., 2016). By another definition, recreation is any activity that people attend voluntarily in any time frame (free time) out of their mandatory tasks in life and achieve satisfaction in return. They are also described as activities that people join voluntarily to make use of their free time (Hazar, 2014).

Participation in recreational activities mitigates stress and anxiety, improves the state of health, maintains good health, promotes positive social interactions, helps people feel well and make reasonable and efficient use of time, improves their physical and psychological state, boosts their sense of self and self-confidence, and improves their recreational skills ( $\mathrm{Li} \&$ Wang, 2012). The concept of

\section{Abstract}

Adopting the suitable sampling method, the sampling group of the study was selected on a voluntary basis out of university students who study for various faculties and departments. The sample of the study consisted of a total of 764 university students including 490 women $(64.1 \%)$ and 274 men (35.9\%). The Recreational Awareness Scale and the Satisfaction With Life Scale (SWLS) were adopted to assess the awareness of subjects about attending events as a part of the study. The results indicated a significant difference in sub-dimension of pleasure \& fun of Recreational Awareness Scale based on age while there was no significant difference in terms of the length of weekly free time. The difference between subjects in scores of satisfaction with life was significantly based on their wellbeing. It was evidenced that the relationship between recreational awareness and satisfaction with life was significant in a positive way. The limitations to the study and assessments over further studies were discussed in this regard.

recreational awareness stands for the awareness of people about the benefits of engaging in recreational activities (Ekinci \& Özdilek, 2019).

In a study performed on university students from 14 different cultural backgrounds, Joshanloo et al., (2016) analyzed the relationship between happiness and satisfaction with life and argued that the needs for selfrealization and safety have a positive impact on satisfaction with life. In a study, Demirel (2019) detected a significant relationship between happiness and engaging in free-time activities. In a study performed on university students, Serdar et al., (2018) found out that the more satisfied people are with their free time, the happier they become.

This study analyzes the relationship between the recreational awareness of university students and their satisfaction with life.

\section{Materials and methods:}

The population of the study consisted of individuals studying in various departments of universities. The subjects to be part of the sampling were selected based on the suitable sampling method, and the sampling group consisted of a total of 764 university students including 490 women (64.1\%) and 274 men (35.9\%). Developed by Ekinci \& Özdilek (2019), the Recreational Awareness Scale was adopted as a data collection tool to measure the awareness 
of the subjects about engaging in recreational activities. The total internal consistency score of the scale turned out to be .94 . In addition, the Satisfaction with Life Scale (SWLS), which was developed by Diener et al., 1985, was adopted. As a part of their original study, Diener et al. reported that the reliability of the scale was Alpha $=.87$, and the criterion validity was .82 . The reliability coefficient was determined to be .57 for the study. The scale was adapted into Turkish by Yetim (1993).

For the analysis of the data collected as a part of the study, the descriptive statistical methods such as percentage and frequency were adopted to assess personal details of the subjects, and the skewness and kurtosis of the data were checked to see if the data had a normal distribution and then Kolmogorov Smirnov test was performed. The analysis indicated no normal distribution for the data. Jondeau \& Rockinger (2003), argued that the sub-dimensions have a non-parametric distribution once the coefficients of skewness and kurtosis range from +3 to -3 $\mathrm{r}(\alpha=0.05)$. In addition to descriptive statistical methods, Mann-Whitney U, Kruskal Wallisö and Spearman Relationship measures were adopted for the statistical analysis of the data $(\alpha=0.05)$.

\section{Results:}

Based on the results of the Mann-Whitney U test, Table 1 indicates a significant Relationship between gender of subjects and their satisfaction with life and a significant difference in Self-Improvement sub-dimension of the Recreational Awareness Scale while there was no significant difference between other sub-dimension scores ( $p>0.05)$.

Table-1: Scores of satisfaction with life and recreational awareness by age of subjects

\begin{tabular}{llllll}
\hline Sub-Dimensions & Variable & $N$ & Mean Rank & $X^{2}$ & $p$ \\
\hline Satisfaction With Life & $17-20$ & 355 & 383.56 & 5.71 & .057 \\
& $21-24$ & 336 & 392.74 & & \\
Pleasure \& Fun & $\geq 25$ & 73 & 324.97 & & \\
& $17-20$ & 355 & 388.72 & 9.20 & .010 \\
Social Success & $21-24$ & 336 & 391.02 & & \\
& $\geq 25$ & 73 & 307.94 & & \\
Self-Improvement & $17-20$ & 355 & 391.97 & 2.49 & .287 \\
& $21-24$ & 336 & 378.74 & & \\
& $>25$ & 73 & 348.46 & & \\
& $17-20$ & 355 & 387.15 & 4.37 & .112 \\
& $21-24$ & 336 & 387.67 & & \\
\hline
\end{tabular}

Based on Kruskal-Wallis test, Table-2 indicates a significant difference between the age of the subjects and the sub-dimension of Pleasure \& Fun of the Recreational Awareness Scale $(\mathrm{p}<0.05)$ while there is no significant difference in other sub-dimensions and scores of Satisfaction With Life Scale ( $>>0.05)$. It was determined that the subjects aged 21 to 24 with a significant difference had a higher score than the subjects in other age groups, and the significant difference results from the formergroup.
Table-2: Scores of satisfaction with life and recreational awareness by well being of subjects

\begin{tabular}{llllll}
\hline Sub-Dimensions & Variable & $\mathrm{N}$ & Mean Rank & $\mathrm{X}^{2}$ & $\mathrm{p}$ \\
\hline Satisfaction With Life & Poor & 111 & 316.37 & 22.86 & .000 \\
& Normal & 550 & 380.60 & & \\
& Good & 103 & 460.18 & & \\
Pleasure \& Fun & Poor & 111 & 399.95 & 4.66 & .097 \\
& Normal & 550 & 371.69 & & \\
Social Success & Good & 103 & 417.63 & & \\
& Poor & 111 & 389.68 & 4.35 & .114 \\
& Normal & 550 & 373.05 & & \\
Self-Improvement & Good & 103 & 421.46 & & \\
& Poor & 111 & 378.86 & 2.06 & .356 \\
& Normal & 550 & 377.22 & & \\
& Good & 103 & 410.87 & & \\
\hline
\end{tabular}

Based on Kruskal-Wallis test, Table-3 indicates a significant difference between the wellbeing of the subjects and their scores of Satisfaction with Life Scale while there is no significant difference in their scores of sub-dimensions of the Recreational Awareness Scale. It was determined that the subjects with a "Good" level of wellbeing had a higher score than the subjects in other wellbeing groups, and the significant difference results from the formergroup.

Table-3: Results of the relationship test performed for the analysis of the relationship between satisfaction with life (swl) and recreational awareness (ra)

\begin{tabular}{|c|c|c|c|c|c|}
\hline & $\begin{array}{l}\text { Satisfaction } \\
\text { With Life }\end{array}$ & $\begin{array}{l}\text { Pleasure } \\
\text { \& Fun }\end{array}$ & $\begin{array}{l}\text { Social } \\
\text { Success } \\
\end{array}$ & \multicolumn{2}{|c|}{$\begin{array}{l}\text { Self- } \\
\text { Improvement }\end{array}$} \\
\hline \multirow{3}{*}{$\begin{array}{l}\text { Satisfaction } \\
\text { With Life }\end{array}$} & $r$ & 1.000 & & & \\
\hline & $\mathrm{p}$ & . & & & \\
\hline & $\mathrm{N}$ & 763 & & & \\
\hline \multirow[t]{3}{*}{ Pleasure \& Fun } & $r$ & $.212^{* *}$ & 1.000 & & \\
\hline & $\mathrm{p}$ & .000 & $\cdot$ & & \\
\hline & $\mathrm{N}$ & 762 & 763 & & \\
\hline \multirow[t]{3}{*}{ Social Success } & $r$ & $.253^{* *}$ & $.773^{* *}$ & 1.000 & \\
\hline & $\mathrm{p}$ & .000 & .000 & $\cdot$ & \\
\hline & $\mathrm{N}$ & 762 & 763 & 763 & \\
\hline \multirow{3}{*}{$\begin{array}{l}\text { Self- } \\
\text { Improvement }\end{array}$} & $r$ & $.269^{* *}$ & $.725^{* *}$ & $.853^{* *}$ & 1.000 \\
\hline & $\mathrm{p}$ & .000 & .000 & .000 & \\
\hline & $\mathrm{N}$ & 762 & 763 & 763 & 763 \\
\hline
\end{tabular}

The coefficient of the Relationship between the scores of subjects for the sub-dimensions of Recreational Awareness Scale and their Satisfaction With Life indicated a significant positive Relationship.

\section{Discussion:}

This study assessed the recreational awareness of university students and their satisfaction with life from the perspective of the coefficient of correlation between their gender, age, wel-lbeing, length of weekly free time and their scores in sub-dimensions of Recreational Awareness Scale, and their Satisfaction with Life. Beard \& Ragheb (1983) argued that free time activities of people, their motive and desire to engage in them strike a balance in their psychological state. Based on the internal consistency coefficients of sub-dimensions concerning the Satisfaction 
with Life Scale and Recreational Awareness Scale for the subjects involved in the study, Pleasure \& Fun, which is one of the sub-dimensions of Recreational Awareness, turned out to have the highest internal consistency that corresponded to .935. Ekinci \& Özdilek (2019) reported that the reliability of the total internal consistency of the data collection tool developed to assess the awareness of university students about the benefits of recreational activities was 0.94 and .885 for the sub-dimension of Pleasure \& Fun, and .905 for the sub-dimension of Social Success, and .884 for the sub-dimension of SelfImprovement.

Gendered leisure has been examined in many countries (Gürbüz \& Henderson, 2014). While there was significant difference in favor of women in sub-dimension of SelfImprovement between Satisfaction with Life Scale and Recreational Awareness Scale based on gender, there was no significant different between the scores of other subdimensions. There are studies that bear similarity to the results of this study. In line with free time scores, Lapa (2013) reported a significant difference in women for the sub-dimension of pleasure \& fun based on the scale of perceived freedom. In another study, Yalçin (2019) indicated that women scored a higher level of recreational awareness than men. Unlike the results of this study, Ekinci (2017), and Lu \& Hu (2005) determined in their studies over recreational awareness of university students and level of Chinese students' satisfaction with free time respectively determined that there was not any difference based on gender.

There was no significant difference between the gender of the subjects and their satisfaction with life. In line with the results of this study, Çakir \& Demirel (2019), Soyer et al., (2017), Chow (2005), and Hintikka (2001) determined in their studies that there was no significant difference between the gender of the subjects and how satisfied they are with life. It was also determined that the subjects aged 21 to 24 had a higher score than other age groups in subdimension of Pleasure \& Fun of Recreational Awareness Scale. There was no significant difference between the scores of other sub-dimensions and the Satisfaction With Life Scale. It is safe to say that first-year students adapt to the new environment and their friends quicker once they promote to second year and make use of their free time with their peers while peopleaged 24 and above attach priority to job seeking and marriage upon graduation. As a part of their study, Reed \& Wilson (2006) reported that $91 \%$ of the university students were aware of recreational areas and $73 \%$ of them made use of recreational areas. Sallis \& Owen (1999) reported higher usage of recreational areas for second-year university students, young people and the elderly while King et al. (1995) and Dishman (1994) argued that proximity to sports facilities is an environmental quality described as a potential facto for physical activity in literature, and the close proximity of such a recreational area to any exercise setting reduces psychological and physical barriers to any physical activity. Based on the level of recreational awareness and age groups, Yalçin (2019) reported that the sub-dimensions of social success and selfimprovement were significant for the group aged 26 and above while pleasure \& fun was significant for the group aged 17 to 20 . Unlike the results of this study, Lapa (2013) reported that the scores of satisfaction with free time were higher in the group aged 40 and below than the scores of knowledge\& skill and pleasure \& fun in two other age groups. In a study over workplace managers, Özkan (2018) found out there was no Relationship between recreational awareness of managers and their age.

For the Relationship between the well-being of the subjects and their satisfaction with life, they reported that the subjects with a "Good" level of well-being had a higher score than the subjects with other levels of well-being. They reported no significant difference in the scores of subdimensions of the Recreational Awareness Scale. In a way to corroborate the results of the study, Soyer et al. (2017) reported a significant difference in favor of people with a "Good" level of well-being for the Relationship between the well-being of university students and their satisfaction with life. In addition, Ye et al. (2012) and Power (2008) concluded that there is a significantly positive Relationship between economic incomeand satisfaction with life.

The coefficient of the correlation between the scores of subjects for the sub-dimensions of Recreational Awareness Scale and their Satisfaction With Life indicated a significant positive Relationship. The results of the study bear similarity with the results of the current studies. Based on the results of a correlation analysis, Yalçin (2019) reported a statistically significant Relationship between the scores of entrepreneurships for the subjects and their scores of pleasure \& fun, social success and self-improvement that are sub-dimensions of the recreational awareness scale. In their study, Çakir \& Demirel (2019) indicated a positive and significant Relationship between satisfaction with life and happiness.

In conclusion, it was determined that recreational awareness of the students and their satisfaction with life depend on various parameters. To this end, universities and local authorities are recommended to attach importance to outdoor and indoor recreational activities, and organize various events, seminars and courses to raise the recreational awareness of individuals.

\section{References:}

Ardahan, F., Turgut, T. \& Kalkan, A.K. (2016): Her yönüyle rekreasyon. Pub. by: Detay Yayýncýlýk, Ankara.

Beard, J.G. \& Ragheb, M.G. (1983): Measuring leisure motivation.J. Leisure Res., 15(3):219-228.

Chow, H.P.H. (2005): Life satisfaction among university students 
in a Canadian prairiecity: a multivariate analysis. Soc. Indicat. Res., 70(2):139-150.

Çakir, V.O. \& Demirel, D.H. (2019): A student-oriented study: Analyzing the relationship between happiness and satisfaction with life. J. Edu. Issue., 5(1):150-161.

Demirel, M. (2019): Leisure involvement and happiness levels of ýndividuals having fitness center membership. J. Edu. Learn., 8(6):140-149.

Diener, E., Emmons, R., Larsen, R.J. \& Griffin, S. (1985): The satisfaction with life scale. J. Personal. Asses., 49(2):71-75.

Dishman, R.K. (1994): Advances in exercise adherence. Pub. by: Human Kinetics, Champaign, IL.

Ekinci, N.E. (2017): Üniversite ögrencilerinin rekreatif etkinlikler hakkındaki farkındalıklarının araptırılması. Doktora Tezi. T.C. Dumlupınar Üniversitesi, Saglık Bilimleri Enstitüsü Beden Egitimi ve Spor Anabilim Dalı, Kütahya.

Ekinci, N.E. \& Özdilek, C. (2019): Investigation of university students' awareness of recreational activities. Int. Online J. Edu. Sci., 11(2):53-66.

Gürbüz, B. \& Henderson K.A. (2014): Leisure activity preferences and constraints: perspectives from Turkey. World Leisure J., 56(4):300-316.

Hazar, A. (2014): Rekreasyon ve animasyon. Pub. by: Detay Yayıncılık. Ankara.

Hintikka, J. (2001): Religious attendance and life satisfaction in the finnish general population. L. Psychol. Theol.,29(2):158.

Jensen, C.R. \& Naylor, J.H. (200o): Opportunities in recreation and leisure careers. Pub. by: VGM Career Books, USA.

Jondeau, E. \& Rockinger, M. (2003): Conditional volatility, skewness, and kurtosis: Existence, persistence, and comovements. L. Eco. Dynam. Cont., 27:1699-1737.

Joshanloo, M., Rizwan, M., Khilji, I.A., Ferreira, M.C., Poon, W.C., Sundaram, S. \& Demir, M. (2016): Conceptions of happiness and life satisfaction: an exploratory study in 14 national groups. Personal. Indiv. Diff., 102:145-148.

Kara, F.M., Gürbüz, B. \& Sarol, H. (2018): Yetiskinlerde serbest zamanda sıkılma algısı, algılanan sosyal yetkinlik ve benlik saygısı düzeyinin incelenmesi. Int. J. Sport, Exer. E Train Sci., 4(4):113-121.

Kýng, A.C., Jeffery, R.W. \& Frıdınger, F. (1995): Environmental and policy approaches to cardiovascular disease prevention through physical activity: Issues and Opportunities. Health Edu., 22:499-511.

Lapa, T.Y. (2013): Life satisfaction, leisure satisfaction and perceived freedom of park recreation participants. ProcediaSocial and Behavioral Sci., 93:1985-1993.

Li, C.L. \& Wang, C.Y. (2012): The factors affecting life satisfaction: recreation benefits and quality of life perspectives. Sports Exerc. Res., 14(4):407-418.
Lu, L. \& Hu, C.H. (2005): Personality, leisure experiences and happiness. J. Happiness Studies, 6:325-342.

Mutlu, Ý., Yýlmaz, B., Güngörmüs, H.A., Sevindi, T. \& Gürbüz, B. (2011): Bireyleri rekreasyonel amaçlı egzersize motive eden faktörlerin çepitli degipkenlere göre karpılaptırılması. Selçuk Üniversitesi Beden Eðitimi ve Spor Bilim Dergisi, 13(1):54-61.

Özkan, R.T. (2018): Yöneticilerin Isyeri Rekreasyon Farkındalık algılarının ve etkinliklere katılımlarının incelenmesi. Yayınlanmıs Yüksek Lisans Tezi. Marmara Üniversitesi Saglık Bilimleri Enstitüsü. Beden Egitimi Ve Spor Ana Bilim Dalı. Istanbul.

Power, C.L. (2008): Academic achievement and social involvement as predictors of life satisfaction among college students.J. Undergra. Res., 13(39):128-135.

Reed, J.A. \& Wýlson, D.K. (2006): Awareness and use of a university recreational trail. J. Amer. College Heal., 54(4):227230.

Sallis, J.F. \& Owen, N. (1999): Physical activity and behavioral medicine. Thous and Oaks, Pub. by: Sage Publications. UK.

Serdar, E., Demirel, M., Harmandal, D. \& Donuk, B. (2018): Üniversite ögrencilerinin serbest zaman doyum düzeyleri ve mutluluk düzeyleri arasýndaki ilipki. Sosyal Bilimler Dergisi, 5(28):429-438.

Shaw, I. (1980): Recreational activities in community health care. Aus. J. Physiother., 26(4):135-141.

Soyer, F., Yýldýz, N.O., Demirel, D.H., Serdar, E., Demirel, M., Ayhan, C. \& Demirhan, O. (2017): The ýnvestigation of the relationship between the factors that prevent university students from attending to the recreational activities and the life satisfaction of the participants. J. Human Sci., 14(2):20352046.

Torkildsen, G. (2005): Leisure and recreation management. 5th Edition, Pub. by: Taylor and Francis, Routledge, London.

Tribe, J. (2011): The economics of recreation, leisure, and tourism. Fourth Edition. Pub. by: Routledge, New York.

Yalçın, C. (2019): Üniversite ögrencilerinin rekreatif etkinliklere katılım farkındalıkları ile giripimcilik düzeyleri arasındaki ilipkinin incelenmesi. Yayınlanmamıs Yüksek Lisans Tezi. Dumlupýnar Üniversitesi, Sosyal Bilimler Enstitüsü, Beden Egitimi veSpor Anabilim Dali, Kütahya.

Ye, S., Yu, L. \& Li, K.T. (2012): A cross-lagged model of self-esteem and life satisfaction: Gender differences among Chinese university students. Personal. Indiv. Diff., 52:546-551.

Yetim, Ü. (1993): Life Satisfaction: a study based on the organization of personal projects. Soc. Indic. Res., 29(3):277289 . 